\title{
Analysis of Petrinja 2020 Earthquake (Croatia) and First 500 Aftershocks $>$ M1.0, Identification of Their Sources and Seismogenic Faults
}

Tihomir Marjanac ( $\nabla$ tihomimarjanac@gmail.com )

University of Zagreb Faculty of Science: Sveuciliste u Zagrebu Prirodoslovno-matematicki fakultet https://orcid.org/0000-0001-6318-5071

Marina Čalogović

University of Zagreb Faculty of Science: Sveuciliste u Zagrebu Prirodoslovno-matematicki fakultet

Karlo Bermanec

ProGEO-Croatia

Ljerka Marjanac

Croatian Academy of Arts and Science Department of Technical Sciences: Hrvatska akademija znanosti i umjetnosti Razred za tehnicke znanosti

\section{Research Article}

Keywords: Dinarides, listric fault, strike-slip faulting, coseismic deformations, sand volcanoes, collapse sinkholes

Posted Date: April 27th, 2021

DOI: https://doi.org/10.21203/rs.3.rs-308069/v1

License: () (1) This work is licensed under a Creative Commons Attribution 4.0 International License. Read Full License 


\section{Abstract}

Strong earthquake of M6.4 stroke Petrinja and neighbouring cities of Sisak and Glina in Croatia on December 29th 2020. It was preceded by two foreshocks of M5.2 and M5.0, and followed by a series of aftershocks of various magnitudes and intensities. We have analysed first 500 earthquakes and aftershocks of > M1.0 which occurred from December 28th 2020 to January 19th 2021, their frequency, focal depths, and coseismic surface phenomena. Correlation of focal depths revealed the source of earthquakes was faulting of hanging wall of a listric normal fault with NW-SE strike and dip towards NE. Major fault seems to have caused earthquakes with only minor magnitudes. The strongest two earthquakes of M6.4 and M5.2 were initiated on synthetic fault, whereas M5.0 earthquake was initiated on an antithetic fault. Almost $50 \%$ of all seismic energy of the first 500 analysed seismic events over M1.0 was released on $1 \mathrm{~km}$ and $10 \mathrm{~km}$ deep hypocentres. Focal mechanisms of major earthquakes and strong fore- and aftershocks indicate dextral-slip mechanism, which is also in accordance with the orientation of surface cracks, land faulting and sand volcano trains.

Co-seismic surface phenomena are land cracks and fissures, land faults, sand volcanoes, eruptive springing of ground water, activation of landslides, and formation of dozens of collapse sinkholes which continued to form and grow for about a month following the major earthquake.

\section{Introduction}

Strong earthquakes occur randomly and rarely enough that several generations of geologists may not have experienced a local strong one, even if they live in seismically active area such as South-Central Europe. Experiencing a local earthquake and having access to publicly available earthquake data allows rapid analysis of an earthquake, its aftershocks and their surface manifestations.

On December $28^{\text {th }} 2020$ series of strong earthquakes stroke Croatian cities Glina, Petrinja and Sisak (Fig. 1), as well as neighbouring villages. The strongest M6.4 earthquake occurred on December $29^{\text {th }}$ causing severe damage on masonry houses and buildings, many casualties and seven deaths. This strong earthquake was felt also in Zagreb, at the distance of 40-50 km, and caused additional damage to masonry structures which were severely damaged by previous Zagreb M5.4 earthquake of March $22^{\text {nd }} 2020$.

The earthquake of December $28^{\text {th }} 2020$ is informally referred to as 'Petrinja earthquake' because its epicentres were located very close to the city, although epicentres of most aftershocks were located in Vukomeričke Gorice hills and along the Kupa River valley (Fig. 1).

The main epicentres of December 2020 Petrinja earthquake are located only $23 \mathrm{~km}$ SE from the (revised) location of 1909 Pokupsko earthquake (Herak and Herak 2010) (Fig. 1) which was studied by Andrija Mohorovičić (1910) who then identified velocity discontinuity at the Core/Mantle boundary, today known as МOHO.

Our analysis covers first 500 earthquakes of $>$ M1.0 which occurred from December $28^{\text {th }} 2020$ through January $19^{\text {th }} 2021$, inclusive. We have analysed earthquake periodicities and distribution of epicentres. We also reconstruct seismogenic faults in the upper Crust and discuss on genesis of coseismic surface phenomena. Our goal was to analyse earthquake data as they were happening and decipher their deep source as soon as possible as a guideline for disaster mitigation and relief efforts in the struck region.

\section{Historical Seismicity}

Vukomeričke Gorice hills, Kupa River valley and the foothills of Zrinska Gora Mt. are located 15-65 km S and SE of Zagreb (Fig. 1) which felt all strong earthquakes that struck that area in the past (Mohorovičić 1910). However, there are no reported earthquakes before 1861 when MCS VII earthquake occurred at the foothills of Zrinska Gora. In the period between 1861 and 1906 the area of Vukomeričke Gorice and Kupa River valley were struck by 10 earthquakes of MCS intensity $\mathrm{VI}^{\circ}$, or stronger. There were no reported minor or moderate earthquakes between May $26^{\text {th }} 1906$ and October $8^{\text {th }} 1909$, when the area was struck by strong earthquake of early reported magnitude of M6.0 and MCS intensity of IX` (Cvijanović 1966).

The 1909 earthquake was followed by six strong (>VI $\mathrm{MCS}$ ) aftershocks during the following four months, two occurring on the same day (January $29^{\text {th }}$ 1910) (Cvijanović 1966) and 15 smaller aftershocks (Mohorovičić 1910). Since the seismicity ceased in 1922 (Cvijanović 1966$)$, the Kupa River valley did not experience a notable earthquake in almost a century.

However, strong earthquake occurred $100 \mathrm{~km}$ SE from Petrinja in Banja Luka city (Bosnia and Herzegovina) on October 26 $6^{\text {th }} 1969$. Banja Luka series of earthquakes started with two strong foreshocks (the strongest was M6.0) which preceded the M6.6 earthquake on October $27^{\text {th }}$. The earthquake caused 15 deaths, 1117 casualties and severe damage in the city.

Kupa River valley is identified as one of 17 seismogenic zones of Croatia (Markušić and Herak 1999). The most prominent earthquake in that zone occurred in 1909 (Mohorovičić 1910; Cvijanović 1966; Herak et al. 2009; Herak and Herak 2010) on a seismogenic fault with dextral-slip which belongs to Sava Fault system that represents SW border of Pannonian Basin (Herak et al. 2009). Herak and Herak (2010) reinterpreted the 1909 earthquake data and relocated its epicentre for ca. $8 \mathrm{~km}$ (Fig. 1), and attributed it to the Pokupsko Fault. The earthquake magnitude was recalculated to M5.78, instead of previously reported M6 (Cvijanović 1966) and the hypocentre was located at the depth of $14 \pm 7 \mathrm{~km}$.

\section{Petrinja 2020 Earthquake}

The Petrinja 2020 earthquake occurred on December $28^{\text {th }}$ at 5:28:07 (UTC) with CSEM / EMSC [1] magnitude of 5.2. The epicentre was located 4 km SW of Petrinja city at $45.42^{\circ} \mathrm{N}$ and $16.22^{\circ} \mathrm{E}$ (Fig. 1). Its hypocentre was $10 \mathrm{~km}$ deep, and preliminary reported intensity was $\mathrm{VI}{ }^{\circ} \mathrm{MCS}$. This first shock was followed by 
four aftershocks of M1.7 - M1.8 which occurred after 32, 5, 11 and 32 minutes. The depths of their hypocentres were 13 and $14 \mathrm{~km}$, but one was only $2 \mathrm{~km}$ deep. Second strong (M5.0) earthquake occurred on the same day at 6:49:56 with the epicentre located at $45.42^{\circ} \mathrm{N}$ and $16.28^{\circ} \mathrm{E}$, just $4.7 \mathrm{~km}$ eastward from the first one and only $0.5 \mathrm{~km}$ southward from Petrinja city (Fig. 1). It was followed by one M1.5 aftershock 130 minutes later with hypocentre at the depth of 4 km. This short series of earthquakes was followed by 15.3 hours long period without any $>$ M1.0 aftershock.

The next series of earthquakes started on December $29^{\text {th }} 2020$ at 0:19:01 with M2.8 and at 6:05:50 with only two moderate aftershocks of M2.8 and M2.3 with shallow, 1-2 km deep hypocentres. At 11:19:54 occurred much stronger earthquake of M6.4 with the epicentre located only $0.8 \mathrm{~km}$ westward from epicentre of the first (M5.2) earthquake and $5 \mathrm{~km}$ from Petrinja city. Its location was $45.42^{\circ} \mathrm{N}$ and $16.21^{\circ} \mathrm{E}$ (Fig. 1 ) and hypocentre was $10 \mathrm{~km}$ deep. During the day, followed 30 M1.1 to M4.4 aftershocks with the focal depths of 1-27 km. The M6.4 earthquake was strongly felt in the Zagreb metropolitan area and caused additional damage to the city centre which was badly damaged in March $22^{\text {nd }} 2020$ M5.4 earthquake. Damage was also reported from several locations in Slovenia, e.g. Brežice and Krško cities located 73 and 84 km NW of Petrinja city. Since then, aftershocks are occurring with wide range of magnitudes and focal depths in span from $34 \mathrm{~km}$ to $0 \mathrm{~km}$.

The major (M6.4) earthquake caused several slope failures (land slides), ground cracking, generation of sand/mud volcanoes, eruptions of artesian water and local opening of numerous collapse sinkholes which will be described below.

At the time of major earthquake, the local weather conditions were fair; it was sunny with the temperature of $15^{\circ} \mathrm{C}$ in Petrinja and the air pressure of 999 mbar [2].

\section{Coseismic Surface Phenomena}

The Petrinja 2020 earthquake caused various surface phenomena in the affected area, some of which were truly synchronous with the major shock, and some were initiated by the earthquake but continued for the next month or even longer. These phenomena were reported by eyewitnesses over social networks and media $[3,4,5,6,7,8,9,10]$, as well as in preliminary reports of professional geologists $[11,12]$.

These phenomena are certainly related to geological composition (lithology of shallow subsurface strata, groundwater level) of the subsurface, so they occur in restricted zones. Unfortunately, some phenomena like sand volcanoes and 'geysers' are short-lived and will not survive erosion and modification by rain and snow-melt waters. On the other hand, some phenomena like collapse sinkholes have rather high preservation potential, but will be sooner-or-later filled in by concerned villagers.

Earth cracks and fissures, some in the fields, some cutting asphalt roads and some cutting Sava River artificial levees are reported from Petrinja and Sisak environs, at the distance of 5 - $20 \mathrm{~km}$ from the major earthquake epicentre. Earth cracks were reported from Brest Pokupski located $5 \mathrm{~km}$ from the epicentre, Nova Drenčina at the distance of $9.6 \mathrm{~km}$, Letovanić at $10 \mathrm{~km}$, Sisak at the distance of $15.5 \mathrm{~km}$, Topolovac at $18 \mathrm{~km}$, Hrastelnica at $18.6 \mathrm{~km}$, Palanjek at the distance of 19 km, and Tišina Erdetska at $20 \mathrm{~km}$. Earth cracks are typically several tens of metres long, several tens of centimetres wide (exceptional $1 \mathrm{~m}$ wide crack is reported from Brest Pokupski) and up to $1.5 \mathrm{~m}$ deep, as could be estimated from eyewitnesses and media video reports, and measured in the field near Palanjek village. Cracks developed in asphalt roads are in fact small faults with sinistral slip of few centimetres and a dip of a centimetre or two. Their orientation in the field is seldom reported [e.g. 11], but in Palanjek fissures are striking ENE-WSW and SE-NW. The timing of their formation is coseismic as reported by an eyewitness in Brest Pokupski.

Sand volcanoes are reported from several villages located $5 \mathrm{~km}$ from the major epicentre in Brest Pokupski village, in Nebojan village at the distance of $9 \mathrm{~km}$, in Dvorišće village near Glina city at the distance of $10 \mathrm{~km}$, in Sisak city suburbs at the distance of $15.5 \mathrm{~km}$, and in Palanjek village at the distance of $19 \mathrm{~km}$. In all of these localities the ground fractured during the major earthquake on December $29^{\text {th }}$, and debris-laden water started springing out forming chains of small debris cones akin to volcanoes. The debris was fine sand-size but eruptional cones eventually degraded in the following days by weathering, leaving behind chains of small craters with ca. $1.2 \mathrm{~m}$ deep 'feeder' pipes below. The sand was in most cases grey, but in Palanjek also yellow. Eyewitnesses from Brest Pokupski and Palanjek villages reported also 2-3 m high eruptions of mud-rich water they referred to as 'geysers'.

Changes in the position of water table were also noted in several water wells in the area, some of which suffered significant lowering of water table, and some received additional water which brought in yellow sand from the aquifer. An eyewitness from Brest Pokupski reported springing of warm water from fissures which created 'fog' (probably steam, since the weather was warm).

After the December $29^{\text {th }}$ earthquake numerous collapse sinkholes started forming in Topolovac village located $18 \mathrm{~km}$ from the epicentre, and in Sunja River valley near Borojevići, Mečenčani and Donji Kukuruzari villages located 20 - $27 \mathrm{~km}$ from the epicentre. The collapse sinkholes were opening in the matter of hours, and rapidly growing in size. In the first month since the earthquake 88 sinkholes were open, some over $30 \mathrm{~m}$ in diameter and the depth of 5-6 m, which caused significant concern of the local population. Newly open sinkholes were soon filled with water, but in some the water drained away. Inhabitants of these villages have also reported that such holes in the ground were forming also before, and were filled to continue their land use.

Land subsidence/uplift was reported by media, quoting opposite values for Petrinja and Sisak cities inspired by satellite interferometry data [13]. Satellite radar interferometry also revealed magnitude of lateral slip [14], with different values for western (NW oblique slip with $35 \mathrm{~cm}$ uplift) and eastern (SE oblique slip with subsidence of $28 \mathrm{~cm}$ ) tectonic block. The interferogram was made of two Sentinel-1 radar images which were acquired on December $24^{\text {th }} 2020$ and December $30^{\text {th }}$ 2020. In that period the area experienced one earthquake of M6.4 and two of M5.2 and M5.0, respectively, so the time between the two acquisition covers all three earthquakes and few tens aftershocks. Official data on surface deformation [15] (Državna geodetska uprava, 2021) state that environs of Glina city shifted towards NW in average for $10 \mathrm{~cm}$ and subsided for $10 \mathrm{~cm}$, environs of Petrinja city shifted towards ESE in average for $45 \mathrm{~cm}$, and Sisak city environs shifted towards NE for $10 \mathrm{~cm}$. 


\section{Geology Of Vukomeričke Gorice Hills And Kupa River Valley Seismic Zone}

Geology of Vukomeričke Gorice hills and Kupa River valley is presented in Basic Geological Map sheet Sisak in the scale 1:100.000 (Pikija 1987a) and its Explanatory Notes (Pikija 1987b). This area is a border zone between two major geotectonical units of SE Europe, Croatia in particular; Pannonian Basin and Internal Dinarides (Fig. 1), and the contact of the two is tectonical.

The SW part of Pannonian Basin is structurally symmetrical faulted basin (Prelogović et al. 1998) filled with Neogene clastic sediments with occasional hydrocarbon-bearing sandstones which locally represent productive reservoirs.

The Dinaric unit is structurally faulted anticline (Pikija 1987a) with metamorphic rocks of probable Palaeozoic age in its deep core which crop out in Petrova Gora (Fig. 1). Vukomeričke Gorice (Fig. 1) structure is interpreted as a horst by Velić (1979), which is accepted also by Pikija (1987b). The oldest exposed rocks in the Kupa River valley are Upper Cretaceous limestones with intercalations of weathered volcanic rocks which are transgressivelly overlain by marine sedimentary rocks of Paleogene and Neogene ages (mostly Miocene). The largest part of this area is made of clay-rich clastic sediments of Pliocene/Pleistocene age which form low hills and valleys that are prone to slope instabilities.

The area is dissected by many faults of Dinaric and anti-Dinaric strike (Oluić 1975; Pikija 1987a) (Fig. 2). Major fault with Dinaric (NW-SE) strike is located 3 km from Petrinja city and was identified as normal fault which borders faulted anticline and lowered Petrinja-Sisak tectonic block. Prelogović et al. (1988) recognized dextral-slip character of major faults, including the Sava Fault. Oluić (1975) in his map (Fig. 2) identified also deep faults associated with areas of gravity minima and maxima. Area of gravity minimum is located south of Petrinja city and is bordered on the southern side by NW-SE striking fault which matches the Pokupsko Fault, which is also recognized as a deep dislocation.

Locally, carbonate rocks of Miocene age are karstified, and karst topography characterized by sinkholes forms co-called isolated karst, particularly in Zabjele locality ca. $1 \mathrm{~km}$ W from the Mečenčani village on Plandište hill ca $270 \mathrm{~m}$ a.s.l. where occurs sinkhole field which drains water to Sunja River. Collapse sinkholes also occur at Rasetine ca. 3.4 km NE from Borojevići, and Kosa ca. 4.4 km NE from Mečenčani village. Subsurface karst is represented by caves, e.g. 455 m long Gradusa cave (G in Fig. 2) and 584 m long Šušnjara cave (Garašić and Kovačević 1991) (Š in Fig. 2), which are located 4.4 km NE and 14 km NW from Mečenčani, respectively. Ponors are located on Sunjsko Brdo hill, 1.5 km northward from Mečenčani village. In the Sunja River valley near Mečenčani village occur several springs, and the largest one is utilised for public water supply, and reportedly became turbid after the earthquake.

Deep exploration wells on hydrocarbon productional fields in the vicinity of Sisak city measured temperature of $50^{\circ} \mathrm{C}$ at the depth of $1015 \mathrm{~m}$, and strongly mineralized hydrothermal waters are found in Sisak and Petrinja city surroundings. These are associated with methane and locally with $\mathrm{H}_{2} \mathrm{~S}$ which occasionally causes eruptions of hot water (Pikija, 1987b).

\section{Seismotectonics}

Prelogović et al. (1998) attributed seismicity of Vukomeričke Gorice to the Sava Fault which is normal in character and marks SW margin of Pannonian Basin. Cross-section in their figure 5 shows synthetic and antithetic faults associated with the Sava Fault, and a small tectonic graben near Sisak city. The crystalline basement is located at the depth of ca. $10 \mathrm{~km}$ and is made of granites. They also quote that earthquakes in this zone occur at the depths of 10 to $30 \mathrm{~km}$, and that most prominent faults extend to MOHO which in this area lays at the depth of 32 - $30 \mathrm{~km}$ (Aljinović 1986; Aljinović et al. 1987).

Herak et al. (2009) plotted earthquake foci on a SW-NE section which shows steep seismogenic zone dipping towards the NE. They recognized this fault as a part of the Sava Fault zone. Sava Fault is itself a normal fault dipping towards the NE, and is active since Neogene, but currently reactivated and inverted into a compressional fault with dextral slip.

The identification of seismogenic faults in the Vukomeričke Gorice - Kupa - Petrinja area is hampered by significant terminological controversy. Herak and Herak (2010) attributed the 1909 Pokupsko earthquake to the Pokupsko Fault which is essentially dextral-slip fault with NW-SE strike (1 in Fig 2). However, this fault is referred to as "Petrinja Fault" in The European Database of Seismogenic Faults [16]. However Croatian seismologists [17] refer to the Petrinja Fault as perpendicular to the Pokupsko Fault, and is recognized as sinistral-slip fault which strikes between Glina and Petrinja cities (SW-NE) (2 in Fig. 2)!

\section{Methods}

This study is based on data on recent earthquakes published on-line by European-Mediterranean Seismological Centre (CSEM / EMSC) on their web site [1]. We have analysed only earthquakes of M1.0 and stronger, their time of occurrence (UTC), magnitude, epicentre coordinates, intensity, and focal depth. For the consistency of the data base, we have relied on magnitudes reported by CSEM / EMSC, although we are aware that magnitudes of strong Petrinja earthquakes are reported as lower by Seismological survey of Croatia [18], GEOFON in Potsdam [19, 20, 21] and QRMT in Bologna [22, 23, 24, 25, 26, 27].

The maps of epicentres (Figs. 3, 4) were constructed by Google MyMaps utility [28] after original and revised coordinates published by CSEM / EMSC. All used data are available upon request.

We have also constructed four SW-NE cross-sections showing the depth distribution of hypocentres of the Petrinja earthquakes and their aftershocks. The zone defined by aftershocks was divided into four polygons of ca. $870 \mathrm{~km}^{2}$ each (Fig. 3), and the depth of each hypocentre was presented in a corresponding cross-section (Fig. 4).

All quoted times in this report are UTC, which is 1 hour different (early) from the local winter time. 
We have also undertaken limited field study in the area with reported land fissures and sand volcanoes. We have recorded their orientations, dimensions and collected samples of sand for the provenance study.

\section{Results And Discussion}

Petrinja earthquake occurred without any significant foreshocks after a century since the previous >M5.0 local earthquake that occurred in 1910 (Cvijanović 1966). During this century-long interseismic period the tectonic units were involved in aseismic creep within the quasi-plastic zone in the upper lithosphere (Sibson 1989). Renewal of seismic activity starts with formation of a 'jog' on a fault plane which has to be breached at some point of time. The slip occurs at finite rupture area of a seismogenic fault plane (Sibson 1986a, b) which is bound by foci of aftershocks and micro-earthquakes (cf. Fig 1 in Sibson 1986b).

\subsection{ANALYSIS OF EARTHQUAKES AND AFTERSHOCKS}

During the first day of 2020 seismicity in Petrinja - Sisak environs, strong earthquakes were occurring between 6 and 8 AM (UTC). The same pattern was also observed during the Zagreb earthquake of March $22^{\text {nd }} 2020$, but also reported as a curiosity by Gutenberg and Richter (1949). However, during the following days earthquakes did not follow this pattern and continued throughout the day.

Since the first Petrinja earthquake in 2020, seismicity in terms of number of earthquakes per day was increasing until December $31^{\text {st }}$ when occurred $72>M 1.0$ earthquakes. From January $1^{\text {st }} 2021$ the number of earthquakes per day is decreasing (Fig. 5). The cumulative released magnitude per day ( $\left.\Sigma \mathrm{M}\right)$ is presented in Table, which also follows the increase - decrease pattern of the earthquake frequency. 


\begin{tabular}{|c|c|c|}
\hline date & $n$ earthquakes & $\Sigma \mathrm{M}$ \\
\hline 28.12.2020. & 8 & 21.1 \\
\hline 29.12.2020. & 30 & 84.1 \\
\hline 30.12 .2020 . & 68 & 131.2 \\
\hline 31.12.2020. & 72 & 138.9 \\
\hline 1.1.2021. & 49 & 90.7 \\
\hline 2.1.2021. & 30 & 54.3 \\
\hline 3.1.2021. & 28 & 51.0 \\
\hline 4.1.2021. & 21 & 40.3 \\
\hline 5.1.2021. & 18 & 32.6 \\
\hline 6.1.2021. & 17 & 30.8 \\
\hline 7.1.2021. & 19 & 36.4 \\
\hline 8.1.2021. & 15 & 29.2 \\
\hline 9.1.2021. & 12 & 21.7 \\
\hline 10.1.2021. & 15 & 28.3 \\
\hline 11.1.2021. & 10 & 22.3 \\
\hline 12.1.2021. & 15 & 26.9 \\
\hline 13.1.2021. & 4 & 6.0 \\
\hline 14.1.2021. & 9 & 16.6 \\
\hline 15.1.2021. & 16 & 30.8 \\
\hline 16.1.2021. & 12 & 19.1 \\
\hline
\end{tabular}

Page 6/20 


\begin{tabular}{|lcc|}
17.1 .2021$. & 7 & 14.2 \\
18.1 .2021$. & 9 & 11.6 \\
19.1 .2021$. & 11 & 18.0 \\
\hline
\end{tabular}

Aftershocks occurred in groups with short delay of several minutes to several tens of minutes, separated by 'quiet' periods with duration of one to several hours (Fig. 6).

The earthquake magnitudes are found to be unrelated to the time of occurrence in a sequence (Fig. 7), especially >M4.0 earthquakes which occurred at random intervals.

The shallowest-foci earthquakes ( $0 \mathrm{~km}$ ) had magnitudes in span from M1.2 to M2.0 (Fig. 8), whereas magnitudes of deeper earthquakes are increasing in span, though the majority were between M1.1 and M2.0. Maximal earthquake magnitudes are increasing in the depth zone between $0 \mathrm{~km}$ and $8 \mathrm{~km}$ from M2.0 to M4.9. At the focal depth of $10 \mathrm{~km}$ magnitudes range from M1.1 to M6.4, whereas between $11 \mathrm{~km}$ and $15 \mathrm{~km}$ occurred M1.1 to M3.8 earthquakes. Only few hypocentres with magnitudes of M1.1 - M2.3 are located at the depths over $15 \mathrm{~km}$. Below the focal depth of $10 \mathrm{~km}$, maximal magnitudes are decreasing, and their distribution follows the curve of shear resistance vs. depth in Sibson (1986a, 1989).

Seismic activity is restricted to the upper part of deforming continental crust and its lower boundary is set to the upper limit of greenschist facies metamorphic zone defined by temperature of $300-350^{\circ} \mathrm{C}$ (Chen and Molnar 1983; Sibson 1983, 1989). The base of seismogenic zone ('regime' of Sibson 1989) is a transition zone between frictional faulting zone above and quasi-plastic shearing flow zone below. The lower boundary of this semi-brittle zone for quartzofeldspatic crystalline rocks is set to $450^{\circ} \mathrm{C}$. Geothermal gradient of $50^{\circ} \mathrm{C} / \mathrm{km}$ (Pikija $1987 \mathrm{~b}$ ) indicate the temperature of $500^{\circ} \mathrm{C}$ at the depth of $10 \mathrm{~km}$. Consequently, formation temperature of $300^{\circ} \mathrm{C}$ would be at the depth of $6 \mathrm{~km}$, whereas $450^{\circ} \mathrm{C}$ would be at the depth of $9 \mathrm{~km}$. However, the strong Petrinja earthquakes, as well as many aftershocks had their hypocentres at the depth of $10 \mathrm{~km}$, which is actually below the greenschist facies metamorphic zone. This could mean that either the hypocentre depths are overestimated, or the geothermal gradient is lower. Since the temperature of $50^{\circ} \mathrm{C}$ was measured in $1 \mathrm{~km}$ deep nearby borehole, we assume the value as correct, and the focal depth seems to be overestimated.

Sibson (1989) holds that the fault slip during rupture propagation is restricted to a narrow zone which migrates along the fault plane lagging behind the advancing rupture front for only a few kilometres.

Foreshocks apparently relate to $\beta$-phase of seismic cycle defined by Sibson (1986a, 1989) as preseismic inelastic deformation, which follows century-long aphase of mainly elastic strain deformation. Main earthquake shock occurs in $\mathrm{y}$-phase defined by fault rupturing and release of energy. Aftershocks are part of postseismic $\delta$-phase.

Earthquakes with the focal depth of 0-2 km were generated by brittle faulting which released minor amount of energy, but caused noticeable shaking at the surface with the reported intensity of $I^{\circ}$ to $\mathrm{IV}^{\circ} \mathrm{MCS}$.

Fig. 9 illustrates the 'efficiency' of hypocentres in terms of cumulative magnitudes $(\Sigma M)$ of foci versus their depths. Large number of earthquakes at focal depth of $1 \mathrm{~km}$ yielded $\Sigma \mathrm{M}$ of 234.1, whereas at the focal depth of $10 \mathrm{~km}$ occurred earthquakes with $\Sigma \mathrm{M}$ of 237.1 . In relation to the total released magnitude $\left(\mathrm{TM}_{500}\right.$, cumulative magnitude of all 500 earthquakes), hypocentres at the depth of $1 \mathrm{~km}$ contributed with $25 \%, 2 \mathrm{~km}$ to $9 \mathrm{~km}$ deep hypocentres released $33 \%$, hypocentres at the depth of $10 \mathrm{~km}$ released $25 \%$, whereas those at the depths over $10 \mathrm{~km}$ released only $13 \%$ of $\mathrm{TM}_{500}$. Very shallow earthquakes, with

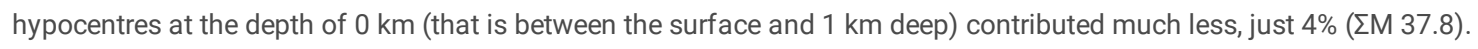

Frequency analysis in Fig. 10 shows increase in the number of earthquakes from M1.0 to maximum at M1.6 and almost linear decrease until M3.0 where we see new increase to M3.8, which is followed by low frequency of M4.0 and stronger earthquakes which may be the effect of incomplete data base since our analysis is based on the first 500 seismic events instead of the full suite which may be due in a year or more. Alternatively, this pattern may be caused by superposition of two seismic cycles.

Strong earthquakes are essentially events independent from their aftershocks since they occur at different focal depths and are caused by different fault mechanisms (Fig. 4). Consequently, the stress at major seismogenic fault which generates strong earthquakes cannot be "released" in a series of smaller earthquakes which would act as a "safety valve" to delay a strong one (Gutenberg and Richter 1949). So, secondary strong earthquakes may occur at any time following the major one, regardless of the number and magnitude of aftershocks (Fig. 7), which should be taken as a warning to relief workers in the earthquake site.

\subsection{RECONSTRUCTION OF SEISMOGENIC FAULT}

The distribution of aftershock epicentres (Fig. 3) outlines the extent of seismogenic fault and its branches. The length of a normal seismogenic fault is about three times the depth of its hypocentre, but for strike-slip fault the ratio is much bigger, 10:1 (Doglioni et al. 2015) what suggests that the rupture length for major Petrinja earthquakes (whose hypocentres were $10 \mathrm{~km}$ deep) would be $100 \mathrm{~km}$ long. However, the faults in subsurface are best illustrated by depth distribution of hypocentres (Fig. 4).

Seismic cross-sections in Fig. 4 reveal aseismic zone located south-westward in the Internal Dinarides area, as well as in the western margin of Pannonian Basin. Seismic zone is 25-35 km wide and over $80 \mathrm{~km}$ long, and reaches into the earth crust down to ca. $20 \mathrm{~km}$, with only few earthquakes with deeper foci. 
Most of the Petrinja earthquake aftershocks occurred at two distinct depth zones; $10 \mathrm{~km}$ deep (as were the foci of $>\mathrm{M} 5.0$ earthquakes) and between the depth of $1 \mathrm{~km}$ and $0 \mathrm{~km}$. The deep hypocentres were activated already on the day of the major (M6.4) earthquake and sporadically provided low-magnitude aftershocks.

Rupture of the Petrinja earthquake was nucleated at the depth of $10 \mathrm{~km}$ and propagated north-westwards along the seismogenic fault at average velocity close to that of shear waves (ca. $3 \mathrm{~km} / \mathrm{s}$, Sibson 1989). Length of rupture is in direct correlation with the duration of faulting, which is directly related to the earthquake duration and surface effects. Given the fault length of $100 \mathrm{~km}$, as estimated after the depth of hypocentre of $10 \mathrm{~km}$ (as suggests $10: 1$ relationship for strike-slip faults in Doglioni et al. 2015), faulting should last for 33 seconds. But, if we take into account the reconstructed length of seismogenic fault 3 of $38.5 \mathrm{~km}$, faulting should last for 12.8 seconds.

Subsurface ruptures are probably best estimated by distribution of early aftershocks (Wells and Coppersmith 1993) which define the maximum extent of coseismic rupture. Because shallow foci- and deep-foci earthquakes occur on different ruptures, and their mode of initiation is different, we have focussed only on aftershocks which were generated at the same depth as the major one, $10 \mathrm{~km}$ during the first day of the M6.4 earthquake.

The distribution of $10 \mathrm{~km}$ deep foci earthquake aftershocks within 10 hours after the M6.4 earthquake delineates the active rupture zone, which is $59 \mathrm{~km}$ long (Fig. 3). That zone is "masked" by the following aftershocks which originated on several, or many, secondary faults some of which may even have surface expression (Fig. 2). Such great length of rupture explains strong manifestations of the major earthquake in Zagreb city, significant damage in Zaprešić city NW of Zagreb and in Krško (Slovenia) which are located $12 \mathrm{~km}$ and $32 \mathrm{~km}$ from the expected NW tip of the rupture, respectively.

The depth distribution of Petrinja earthquake hypocentres (Fig. 4) shows wedge-shape grouping with NE dipping deep fault 1 which borders aseismic from seismic zone and seems to extend to the depth of $20 \mathrm{~km}$, but with low seismicity below $10 \mathrm{~km}$. This major fault (1) may be considered a 'boundary' fault which strikes NW-SE and extends for almost the full length of the area defined by epicentres (Fig. 3). Correlation of seismic cross-sections (Fig. 4) indicates that the fault 1 is at least $60 \mathrm{~km}$ long and dips with the inclination of $30^{\circ}-40^{\circ}$. The active part of the fault 2 is at least $66 \mathrm{~km}$ long and dips towards NE with inclination of $40^{\circ}-55^{\circ}$. Fault 3 which generated two strong earthquakes M6.4 and M5.2 is $38.5 \mathrm{~km}$ long, but it was not recognized in panel A (Fig. 4). Antithetic faults 4 and 5 are also unrecognized in panel A, so their length is seemingly shorter, 36 and $36.5 \mathrm{~km}$, respectively. Both faults dip towards the SW with inclination of $45^{\circ}-50^{\circ}$.

Hypocentres are clustered along secondary faults 2 and 3 with generally the same, or very similar position as the major fault 1 and represent synthetic faults. Faults 4, 5, and 6 dip in the opposite direction, towards SW, and these are interpreted as antithetic faults. The first (M5.2) earthquake seems to have originated on synthetic fault 3 dipping towards the NE, whereas the second (M5.0) earthquake seems to have occurred on antithetic fault 5 (Fig. 4 , block D). Major M6.4 earthquake occurred on the same synthetic fault (3) as the first earthquake (Fig. 4, block C). The focal mechanism of the first (M5.2) earthquake shows dextral oblique slip with compressional component [20,22], whereas the mechanism of major (M6.4) earthquake indicated dextral strike-slip [19, 23], as does also for other analysed aftershocks $[21,24,25,26,29]$. Dextral slip, as well as dextral oblique slip (with reverse component) mechanism of these faults document primarily lateral-slip movement on the respective seismogenic faults.

The focal depths of major earthquakes (>M5.0) is $10 \mathrm{~km}$, and similar is reported for many strike-slip fault earthquakes (e.g. Gutenberg and Richter 1949). This depth corresponds to the depth which is characterized by major change on rheology of the basement rocks, ductile below and brittle above (Strehlau 1986; Scholz 1988; Sibson 1989). Since the rocks, presumably crystalline, under the geostatic pressure and temperature at that depth have ductile properties, below is essentially aseismic zone. Only four earthquakes had deeper hypocentres (Figs. 8, 9), namely at 24, 26, 27 and 34 km, but their magnitudes were low, between M1.3 and M1.6. As earthquake rupture progressed upwards and laterally, it probably prolonged also downwards into aseismic zone (Strehlau 1986; Scholz 1988) which is characterized by quasi-plastic shearing flow (Sibson 1989). On the other hand, numerous very shallow-foci earthquakes are caused by brittle behaviour of rocks under low geostatic but high hydraulic pressure exerted by upward migrating water which is expelled from deep-seated watersaturated sandstones or other porous rocks. This water is typically expelled from micropores in clastic rocks under tectonical stress by "fault valving" (Sibson 1990).

Tectonical reconstruction of foci clustering may indicate either normal listric fault with hanging wall collapse (Fig. 11), or a positive flower structure. However, the first interpretation seems to better fit the regional geological setting.

\subsection{COSEISMIC PHENOMENA}

The formation of fissures and cracks in soil are reported from many historical earthquakes. In this case they all occurred in soil on fluvial terraces of Kupa (Brest Pokupski) and Sava River (all others), and artificial levees of the Sava River left bank. Some fissures are associated with springing of fine debris-rich water from the ground and formation of the so-called sand volcanoes.

Reported sand volcanoes were formed in long chains with dozens of small craters gushing out with debris-rich water that built eruptional cones. Early interpretations associated this phenomenon with liquefaction [11], which is by definition the process of liquidization of permeable water-saturated cohesionless sediment under static conditions or induced by cyclic stress of an earthquake (Allen 1982), in which grains become dispersed in water followed by sand injections and formation of sand/mud volcanoes that are common coseismic phenomenon (Allen 1982; Galli 2000). However, in many cases liquefaction may also occur aseismically (e.g. Ricci Lucchi 1995). Fluidization is another process of liquidization (Lowe 1975; Allen 1982) which implies upward directed flow of water that fluidizes cohesionless sediment. It may occur due to compressional stress and closure of water-saturated micropores in sand aquifer that forces water to migrate upwards through fluidization pipes. This upward expulsion of water forces formation of cracks and fissures in soil. The reported warm spring waters emanating from fissures may be caused by expulsion of thermal waters along the deep faults which functioned as open valves during the earthquake (e.g. Sibson 1990; Muir-Wood and King 1993; Doglioni et al. 2015). The pressure of ground water was locally high to account for 
occurrence of artesian and subartesian waters. Reported 'geysers' are rare events of violent springing of artesian water. However, deep subsurface of Kupa River valley area hosts thermal waters which were drilled in hydrocarbon exploration wells (Pikija 1987b), and are utilized in Topusko spa 32 km SW from the epicentre.

Water that springs in sand volcanoes is expelled from micropores and cracks in porous aquifer, which are open in interseismic period providing essential porosity and permeability of the aquifer, but close during an earthquake which is typical for normal-and strike-slip fault earthquakes (Muir-Wood and King 1993). This coseismic fault valving may be also manifested as changes of water level in water-supply wells (Sneed et al. 2003) and as the increase of flow discharge of local streams and rivers that may last for several months following a major earthquake (Muir-Wood and King 1993).

Early interpretations associated the formation of collapse sinkholes in the Mečenčani village area with 1) compaction of water-saturated sand [7], and 2) of uplift and subsidence of land surface and action of ground waters [8]. Formation of collapse sinkholes is a matter of long-lasting debate. They are rarely recognized as a coseismic phenomenon, but nevertheless there are several historical accounts on opening of new sinkholes during Central Apennine earthquakes in 1703 and 1997, and enlargement of some sinkholes after L'Aquila earthquake in 2009 (Santo et al. 2011). Since collapse sinkholes in Banija region have been forming before, their formation in this large number is certainly associated with significant change in the position of ground water table, and its dynamics. We associate the formation of these collapse sinkholes to karst processes, since the Mečenčani village is surrounded by isolated karst. Several springs in the Sunja River valley near Mečenčani village document locally high water table and possibly a buried hydrological barrier which favoured their formation. Thus, in our opinion Mečenčani collapse sinkholes are formed due to collapse of buried cave system; either due to lowering of the ground water table, or due to significant increase of ground water which opened buried estavelas. Which of the two possible processes was responsible for their formation at this locality is currently hard to tell.

Deformations of surface in the Petrinja-Glina area were first associated with collapsing of roofs of abandoned coal mines [9]. However, the closest historical coal mining was in Vukomeričke Gorice near Kravarsko, 25 km NW from Petrinja, and near Madžari village 13 km SE of Petrinja (Pikija 1987a; Marković 2002), so the sand/mud volcanoes near Dvorišce village and other surface phenomena described above are unrelated to abandoned coal mining, but a consequence of subsurface processes like water expulsion from sand aquifers.

Land subsidence is well known phenomenon associated with almost all earthquakes. The subsidence, however, may have different causes; it may be true down-slip of a tectonic block along a fault (in case of normal fault its hanging wall slipped down), but also it can occur due to liquefaction and dewatering of sandy aquifers. Water expulsion was reported from several localities around Petrinja, but also near Sisak city. Documentation of different topography before and after the earthquake, as revealed by satellite radar interferometry based on comparison of two radar images acquired two days or more apart [14], as well as by high-precision geodetic survey [15], indicates cumulative effect of many earthquakes that occurred in the time span between two satellite flyovers and successive geodetic surveys. Consequently, it is hard to tell which of the earthquakes contributed more, or to which component of deformation. Numerous shallow-foci earthquakes are likely to produce near surface deformations, unlike few deep-foci earthquakes which occurred on the boundary between fragile and ductile rocks in lithosphere.

\section{Conclusion}

Since the start of seismic activity in 2020, the maximal frequency in terms of number of earthquakes per day and cumulative magnitude of daily events was reached on the fourth day, and from than on the activity is on decrease. The maximal earthquake magnitudes are increasing until the depth of $10 \mathrm{~km}$, and from there decreasing with depth.

Geothermal gradient of $50^{\circ} \mathrm{C} / \mathrm{km}$ suggests the temperature of $500^{\circ} \mathrm{C}$ at the hypocentral depth of major earthquakes, which casts doubt in validity of the estimates of focal depths, which are probably overestimated.

The rupture of Petrinja earthquakes was nucleated at the depth of $10 \mathrm{~km}$ and propagated along the fault plane which was ca. $38.5 \mathrm{~km}$ long, but the distribution of first-day aftershocks at the depth of $10 \mathrm{~km}$ suggests the length of about $59 \mathrm{~km}$.

The distribution of first 500 hypocentres on seismic cross-sections allowed for recognition of several discrete fault planes, all of which strike NW-SE, but some with opposite dip directions. The major fault is a listric normal fault dipping towards NE, along with two synthetic faults. Two antithetic faults dipping towards SW are also recognized. The first (M5.2) and the strongest (M6.4) earthquake occurred on the same synthetic fault which is over $38 \mathrm{~km}$ long, probably reaching $60 \mathrm{~km}$ in length. The second strong earthquake (M5.0) in the sequence originated on an antithetic fault.

Sand volcanoes were formed in response to expulsion of ground water during coseismic closure of micropores associated with strike-slip faulting which caused the strongest earthquake in the seismic sequence.

Post-seismic formation of numerous collapse sinkholes in the area of isolated karst is attributed to collapsing into buried karstified bedrock due to major change in ground water level, which was caused by coseismic change in water table.

Changes in topography, subsidence and lateral shift of geodetic markers are cumulative effects of all earthquakes which struck the wider Petrinja-Sisak area, caused predominantly by dextral strike-slip faulting.

\section{Acknowledgments}

This research was not funded from any sources, and all authors are affiliated as volunteers in non-profit NGO ProGEO-Croatia for popularization and protection of geological heritage. We are indebted to all local eyewitnesses of the earthquake and contributors of media reports whose testimonies made the

Page 9/20 
analysis of coseismic deformation phenomena possible. We are also indebted to retired prof. Marinko Oluić who stimulated fruitful discussions on seismotectonics of the affected region.

\section{References}

Aljinović B (1986) Karta dubina Mohorovičićeva diskontinuiteta na području Jugoslavije. Nafta 37: 127-130

Aljinović B, Prelogović E, Skoko D (1987) Novi podaci o dubinskoj geološkoj građi i seizmotektonski aktivnim zonama u Jugoslaviji. Geol vjesnik 40: 255-263 Allen JRL (1982) Sedimentary structures, their characteristics and physical basis. Vol. 2. Developments in sedimentology 30B, 663 p., Elsevier Sci. Publ. Co. Inc., Amsterdam.

Chen W-P, Molnar P (1983) Focal Depths of Intracontinental and Intraplate Earthquakes and Their Implications for the Thermal and Mechanical Properties of Lithosphere. J Geophys Res 88/B5: 4183-4214.

Christensen AF (1983) An example of a major syndepositional listric fault. In: Bally AW (ed) Seismic expression of structural styles. A picture and work atlas. AAPG Studies in Geology, Ser 15/2, 36-40

Cvijanović D (1966) Jači potresi (\$ VIE MCS) u SR Hrvatskoj. Geol vjesnik 19: 139-167.

Doglioni C, Carminati E, Petricca P, Riguzzi F (2015) Normal fault earthquakes or graviquakes. Nature Sci Rep, https://doi.org/10.1038/srep12110

Državna geodetska uprava (2021) Izvješće: Analiza rezultata preciznih geodetskih mjerenja o pomicanju zemljine kore na potresom pogođenom području. (https://dgu.gov.hr/UserDocsImages/dokumenti/VIJESTI/potres/IzvješceGNSS mjerenja.pdf)

Galli P (2000) New empirical relationships between magnitude and distance for liquefaction. Tectonophysics 324: 169-187

Garašić M, Kovačević T (1991) Speleogeologija Špilje kod Šušnjara - jedinstvenog speleološkog objekta formiranog u laporovitim stijenama (Banija). Spelaeol Croat 2: 31-36

Gutenberg B, Richter CF (1949) Seismicity of the Earth and associated phenomena. Princeton Univ. Press, Princeton

Herak D, Herak M (2010) The Kupa Valley (Croatia) Earthquake of 8 October 1909 - 100 Years Later. Seismol Res Lett 81/1: 30-36

Herak D, Herak M, Tomljenović B (2009) Seismicity and earthquake focal mechanisms in North-Western Croatia. Tectonophysics 465: 212-220

Lowe DR (1979) Sediment gravity flows: their classification and some problems of application to natural flows and deposits. S.E.P.M. Spec Publ 27: 75-82

Marković S (2002) Hrvatske mineralne sirovine. Institut za geološka istraživanja Zagreb, Zagreb

Markušić S, Herak D (1999) Seismic Zoning of Croatia. Nat Hazards 18: 269-285

Mohorovičić A (1910) Potres od 8. X 1909. Godišnje izvješće zagrebačkog meteorološkog opservatorija za godinu 1909. 1-56

Muir-Wood R, King GCP (1993) Hydrological Signatures of Earthquake Strain. J Geophys Res 98, B12: 22035-22063.

Oluić M (1975) Glavne karakteristike tektogenetskog sklopa jednog dijela unutrašnjih Dinarida (područje Zrinske i Trgovske Gore). II godišnji znanstveni skup Sekcije za primjenu geologije, geofizike i geokemije Znanstvenog Savjeta za naftu JAZU, Zagreb 1975., pp. 152-163

Pikija M (1987a) Osnovna geološka karta SFRJ 1:100.000, List Sisak L33-93, Geološki zavod Zagreb, Savezni geološki zavod Beograd.

Pikija M (1987b) Osnovna geološka karta SFRJ 1:100.000. Tumač za list Sisak L33-93, Geološki zavod Zagreb, Savezni geološki zavod Beograd, 1-53

Prelogović E, Saftić B, Kuk V, Velić J, Dragaš M, Lučić D (1998) Tectonic activity in the Croatian part of the Pannonian basin. Tectonophysics 297: 283-293

Ricci Lucchi F (1995) Sedimentological Indicators of Paleoseismicity. In: Serva L, Slemmons DB (eds) Perspectives in Paleoseismology. Assoc Engineering Geol Spec Publ 6, Washington, pp. 7-17

Santo A, Ascione A, Del Prete S, di Crescenzo G, Santangelo N (2011) Collapse sinkholes distribution in the carbonate massifs of Central and Southern Apennines. Acta Carsol 40/1: 95-112

Sibson RH (1983) Continental fault structure and the shallow earthquake source. J geol Soc Lond 140: 741-767

Sibson RH (1986a) Earthquakes and Rock Deformation in Crustal Fault Zones. Ann Rev Earth and Planet Sci 14: 149-175

Sibson RH (1986b) Earthquakes and Lineament Infrastructure. Phil. Trans. R. Soc. Lond. A 317: 63-79

Sibson RH (1989) Earthquake faulting as a structural process. J Struct Geol 11/1/2: 1-14

Page $10 / 20$ 
Sibson RH (1990) Conditions for fault-valve behaviour. In: Knipe RJ, Ruter EH (eds) Deformation Mechanisms, Rheology and Tectonics. Geol soc Lond Sp Publ 54 , pp. $15-28$

Scholz CH (1988) The brittle-plastic transition and the depth of seismic faulting. Geol Rundsch 77/1: 319-328

Sneed M, Galloway DL, Cunningham WL (2003) Earthquakes - Rattling the Earth's Plumbing System. USGS Fact Sheet 096-03

Strehlau J (1986) A discussion of the depth extent of rupture in large continental earthquakes. In: Das S, Boatwright J, Scholz CH (eds) Earthquake Source Mechanisms. Geophys. Monograph 37 (Maurice Ewing Series 6), Am. Geophys. Union, pp. 147-155

Velić J (1979) O razlikovanju neotektonskih struktura u zapadnom dijelu Savske depresije. Geol vjesnik 31: 175-184

[1] www.emsc-csem.org

[2] https://www.timeanddate.com/weather/@3193419/historic?month=12andyear=2020. Accessed 31 January 2021

[3] https://www.fokus.ba/magazin/taj-ludi-svijet/neobicna-pojava-nakon-potresa-zemlja-se otvorila-i-krenula-je-voda-to-su-bili-gejziri/1960104/ Accessed 31 January 2021

[4] https://www.jutarnji.hr/vijesti/hrvatska/seizmolog-sovic-objasnio-zasto-su-nastale-ogromne-rupe-u-zemlji-nakon-potresa-u-petrinji-15040496. Accessed 31 January 2021

[5] https://www.vecernji.hr/vijesti/tijekom-potresa-iz-zemlje-je-sikljala-voda-geolozi-su-rekli-da-se-s-ovim-jos-nisu-susreli-1458575. Accessed 31 January 2021

[6] https://www.jutarnji.hr/life/znanost/geolozi-otkrili-sto-je-uzrokovalo-potrese-ali-i-deformacije-tla-spomenuli-su-i-rudnike-15040801. Accessed 31 January 2021

[7]

https://slobodnadalmacija.hr/vijesti/hrvatska/seizmolozi-objasnjavaju-zasto-su-nakon-potresa-pojavile-velike-rupe-u-zemlji-fiket-nije-iskljucena-mogucnost-r Accessed 31 January 2021

[8] https://www.jutarnji.hr/vijesti/hrvatska/najveca-rupa-kod-petrinje-i-dalje-se-siri-policija-ju-je-ogradila-to-je-sve-sto-se-moze-sada-15022840. Accessed 31 January 2021

[9] https://emedjimurje.net.hr/vijesti/drustvo/3959246/video-i-foto-ogromna-rupa-u-zemlji-u-selu-mecencani-tjera-strah-u-kosti-ovo-nije-normalno/ Accessed 31 January 2021

[10] https://www.jutarnji.hr/vijesti/hrvatska/zemlja-u-palanjku-se-doslovno-otvorila-voda-je-sikljala-dva-metra-u-zrak-to-su-bili-gejziri-15039756. Accessed 31 January 2021

[11]

https://www.rgn.unizg.hr/hr/izdvojeno/2790-izvjesce-o-zabiljezenim-pojavama-koseizmickih-povrsinskih-deformacija-na-podrucju-pokuplja-i-banovine-nasta Accessed 31 January 2021

[12] https://www.hgi-cgs.hr/urusavanje-tla-u-mecencanima-i-okolici-izazvano-potresom-magnitude-6-2-kod-petrinje-te-prethodnim-i-naknadnim-potresima/ Accessed 8 February 2021

[13] https://www.24sata.hr/news/satelitske-snimke-potres-digao-petrinju-12-centimetara-glinske-poljane-propale-7-centimetara-737246. Accessed 31 January 2021

[14] https://www.geof.unizg.hr/novosti/karta-povrsinskih-pomaka-dobivena-satelitskom-radarskom-interferometrijom-za-petrinjski-potres-magnitude-6-3/ Accessed 31 January 2021

[15] https://dgu.gov.hr/vijesti/prvi-sluzbeni-rezultati-satelitskih-mjerenja-na-potresom-pogodjenom-podrucju/5645. Accessed 16 February 2021

[16] http://diss.rm.ingv.it/share-edsf/sharedata/SHARE_WP3.2_Map.html. Accessed 8 February 2021 [17]

http://www.pmf.unizg.hr/geof/seizmoloska_sluzba/potresi_kod_petrinje Accessed 11 February 2021

[18] https://www.pmf.unizg.hr/geof/seizmoloska_sluzba/potresi_kod_petrinje. Accessed 8 February 2021

[19] http://geofon.gfz-potsdam.de/eqinfo/event.php?id=gfz2020zocb. Accessed 31 January 2021

[20] http://geofon.gfz-potsdam.de/eqinfo/event.php?id=gfz2020zluy. Accessed 31 January 2021

[21] http://geofon.gfz-potsdam.de/eqinfo/event.php?id=gfz2020zlxq. Accessed 31 January 2021

[22] http://autorcmt.bo.ingv.it/QRCMT-on-line/QRCMT20-on-line/E2012280528A.html. Accessed 31 January 2021

Page $11 / 20$ 
[23] http://autorcmt.bo.ingv.it/QRCMT-on-line/QRCMT20-on-line/E2012291119B.html. Accessed 31 January 2021

[24] http://autorcmt.bo.ingv.it/QRCMT-on-line/QRCMT20-on-line/E2012280649A.html. Accessed 31 January 2021

[25] http://autorcmt.bo.ingv.it/QRCMT-on-line/QRCMT20-on-line/E2012300515A.html. Accessed 31 January 2021

[26] http://autorcmt.bo.ingv.it/QRCMT-on-line/QRCMT20-on-line/E2012300526B.html. Accessed 31 January 2021

[27] http://autorcmt.bo.ingv.it/QRCMT-on-line/E2101061701A.html. Accessed 31 January 2021

[28] https://www.google.com/maps/about/mymaps/ Accessed 31 January 2021

\section{Figures}

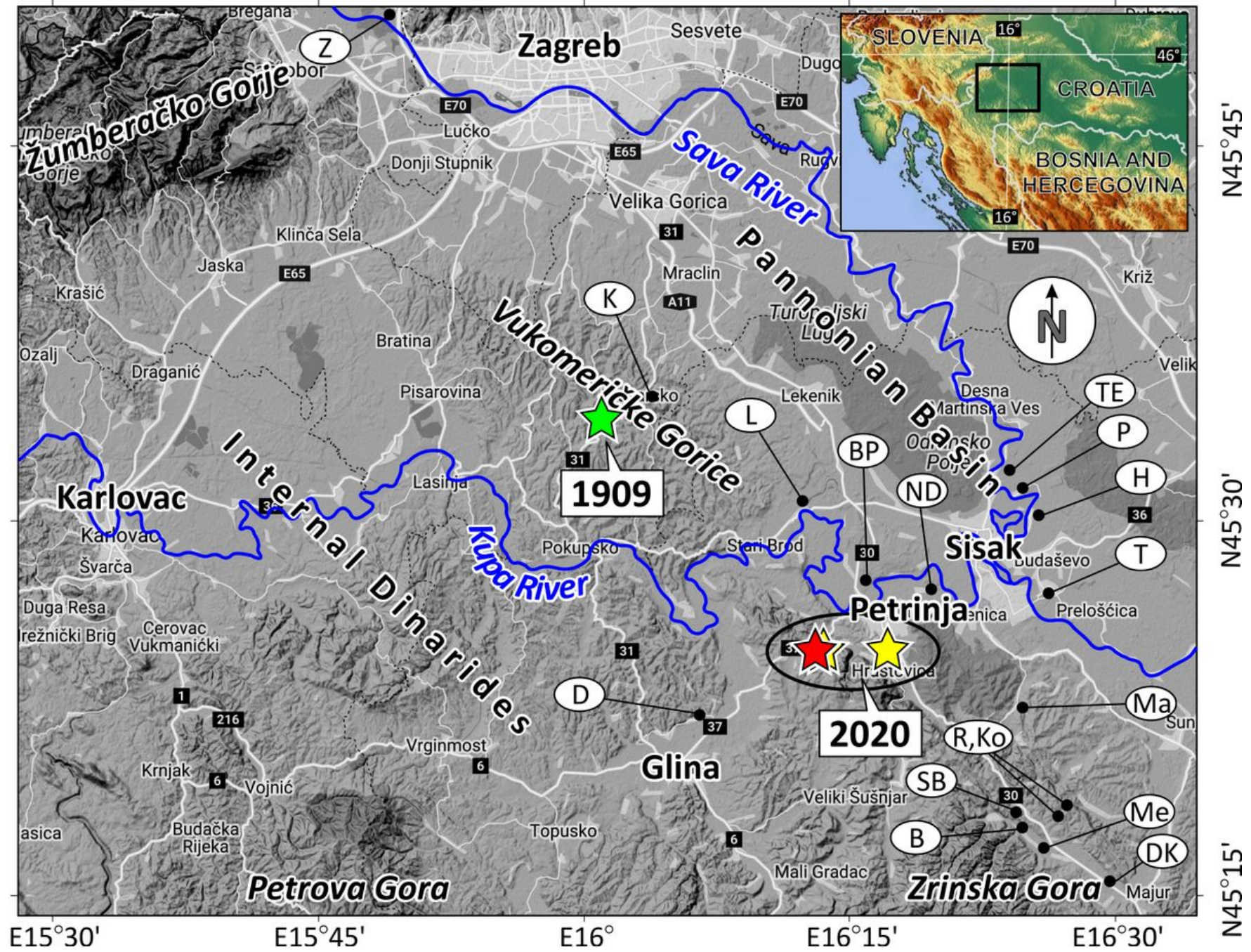

Figure 1

Position map with epicentres of historical (1909) and recent (2020) earthquakes. Key: Z = Zaprešić, BP $=$ Brest Pokupski, ND $=$ Nova Drenčina, $L=$ Letovanić, $T$ = Topolovac, $\mathrm{H}=$ Hrastelnica, $\mathrm{P}=$ Palanjek, TE = Tišina Erdetska, $\mathrm{D}=$ Dvorišće, $\mathrm{B}=$ Borojevići, $\mathrm{Me}=$ Mečenčani, $\mathrm{DK}=\mathrm{Donji}$ Kukuruzari, $\mathrm{R}=\mathrm{Rasetine}$, Ko = Kosa, $\mathrm{SB}=$ Sunjsko Brdo, To = Topusko, $\mathrm{K}=$ Kravarsko, $\mathrm{Ma}=$ Madžari Note: The designations employed and the presentation of the material on this map do not imply the expression of any opinion whatsoever on the part of Research Square concerning the legal status of any country, territory, city or area or of its authorities, or concerning the delimitation of its frontiers or boundaries. This map has been provided by the authors. 

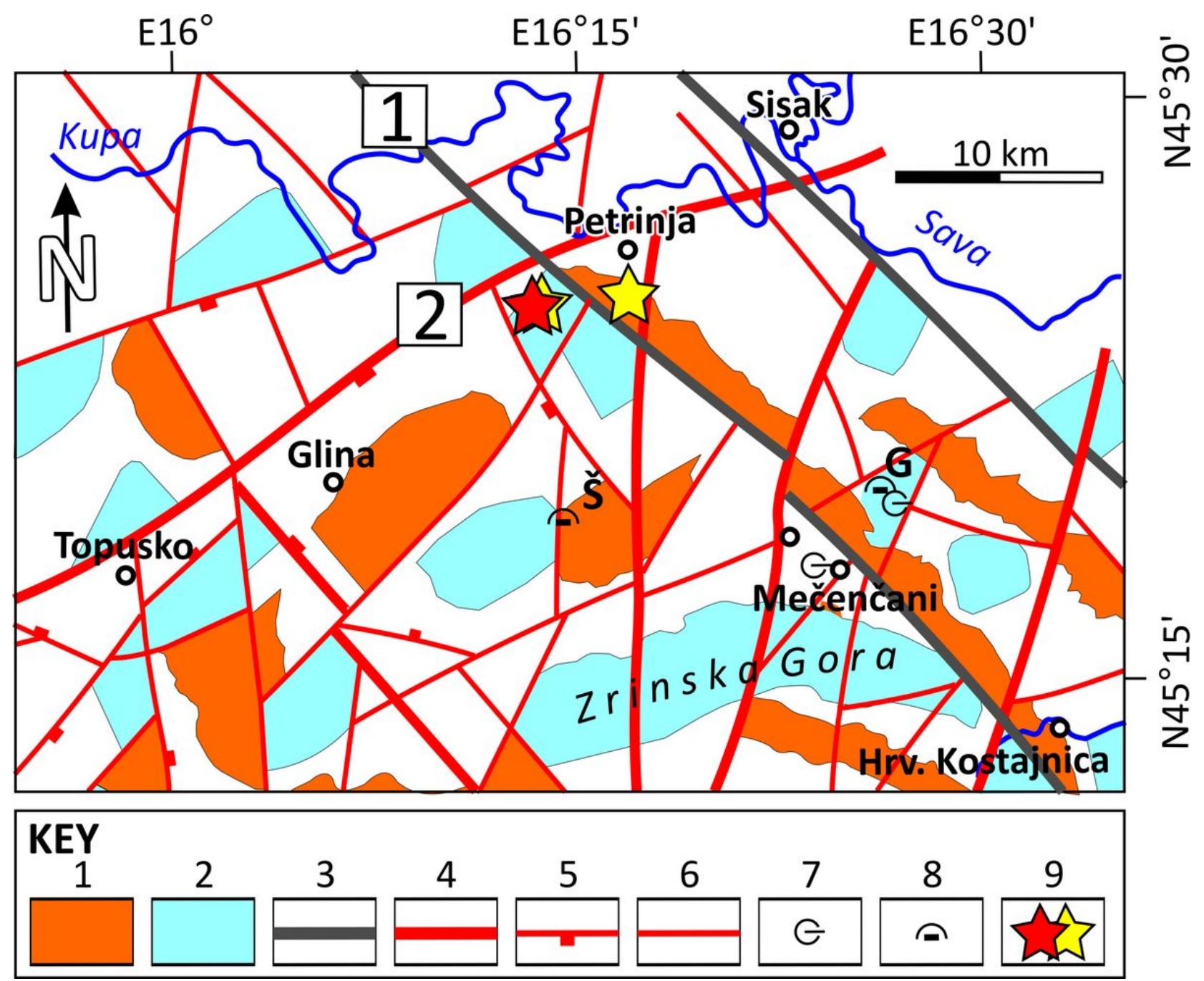

Figure 2

Tectonic map of Banija based on satellite imagery (Oluić 1975), modified. Karst features are added; Š marks location of Šušnjara cave, G marks location of Gradusa cave. Seismogenic faults 1 (Pokupsko Fault) and 2 (Petrinja Fault) discussed in text and also labelled. Key: 1) areas of gravity minima, 2) areas of gravity maxima, 3) deep dislocations (faults), 4) major faults, 5) lowered fault wall, 6) minor faults, 7) sinkhole, 8) cave, 9) epicentres of 2020 earthquakes. Note: The designations employed and the presentation of the material on this map do not imply the expression of any opinion whatsoever on the part of Research Square concerning the legal status of any country, territory, city or area or of its authorities, or concerning the delimitation of its frontiers or boundaries. This map has been provided by the authors. 


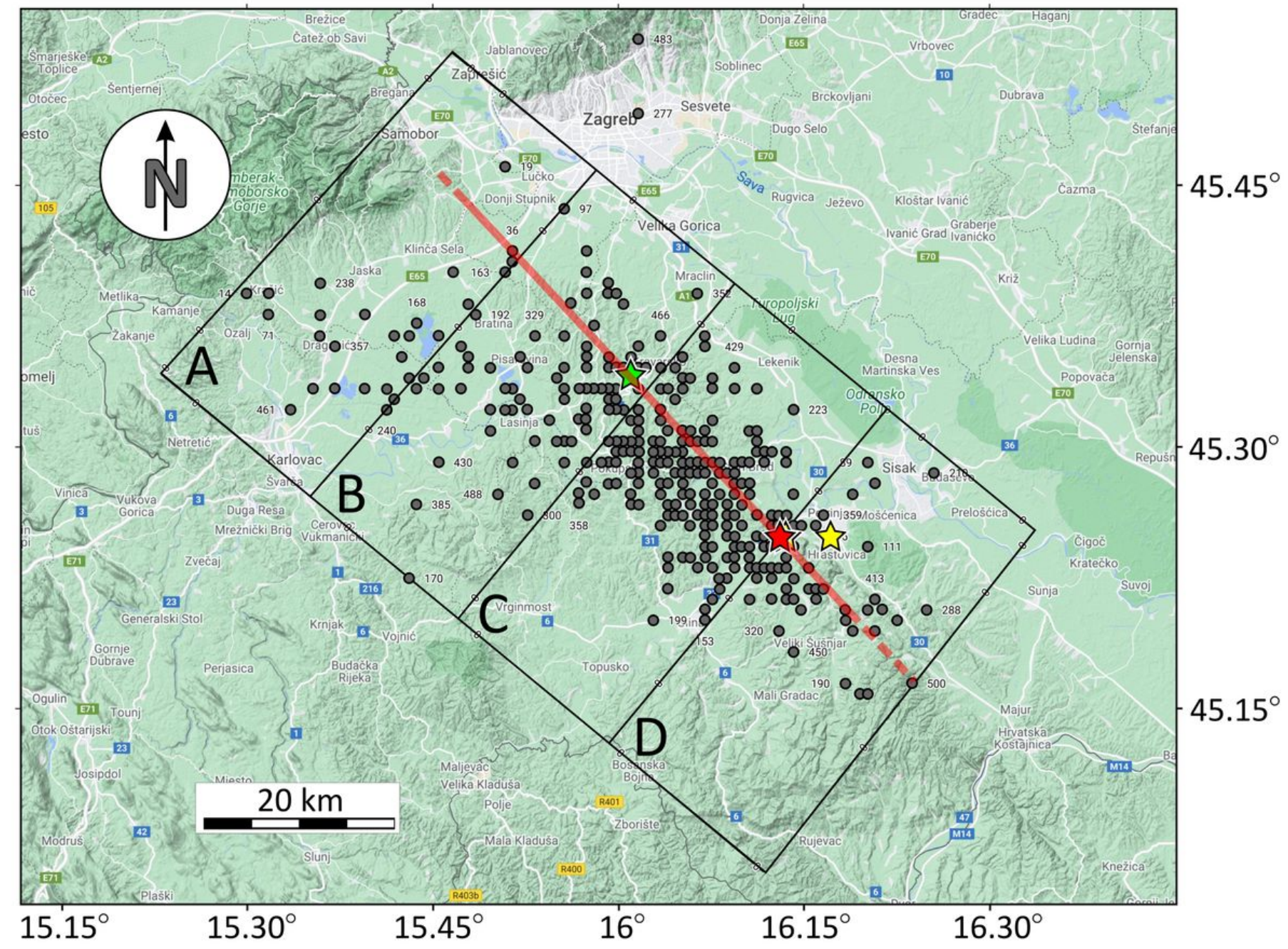

Figure 3

Locations of epicentres of first 500 earthquakes (stars) and aftershocks (dots). A-D are blocks used for construction of seismic cross-sections in Fig. 5. Red line is interpreted seismogenic fault 3. Note: The designations employed and the presentation of the material on this map do not imply the expression of any opinion whatsoever on the part of Research Square concerning the legal status of any country, territory, city or area or of its authorities, or concerning the delimitation of its frontiers or boundaries. This map has been provided by the authors. 


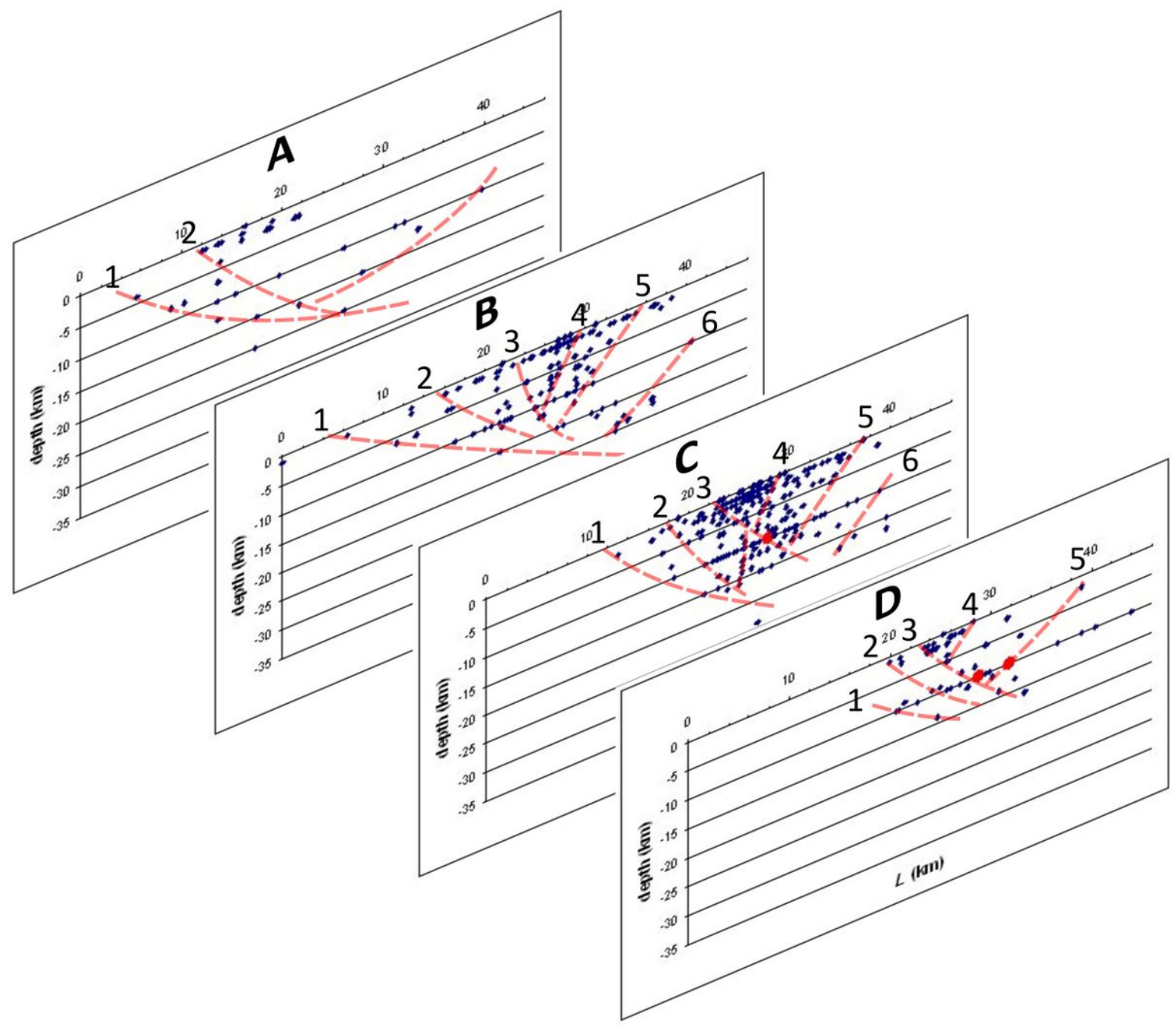

\section{Figure 4}

Interpreted SW-NE seismic cross-sections and their correlation. Individual faults are numbered and discussed in text. Major earthquakes are labelled by red dots. 


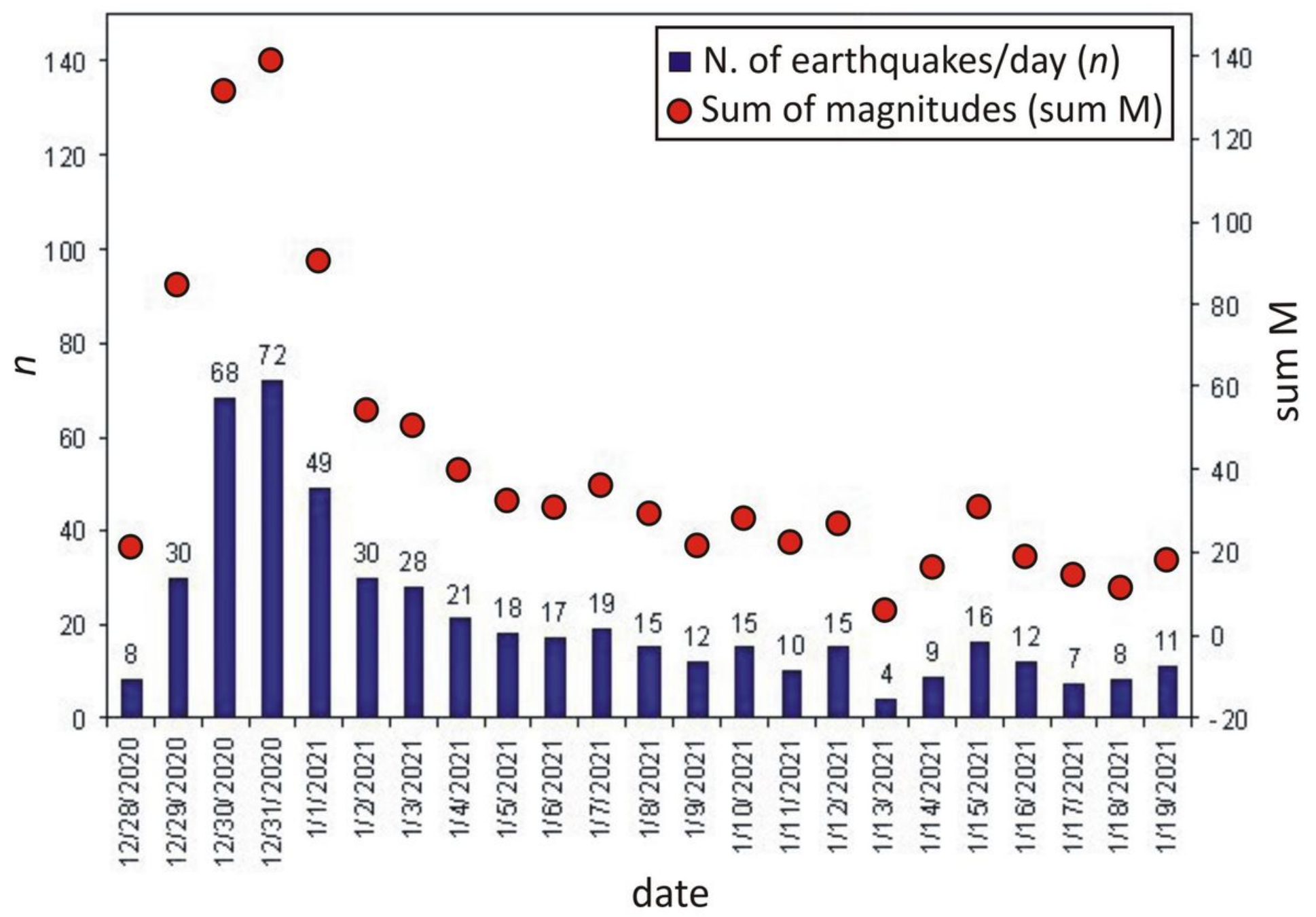

Figure 5

Number of earthquakes and cumulative released magnitude par day, from December 28th 2020 to January 19 th 2021 shows increase during the first 4 days of seismic activity, and its decrease in the following days.

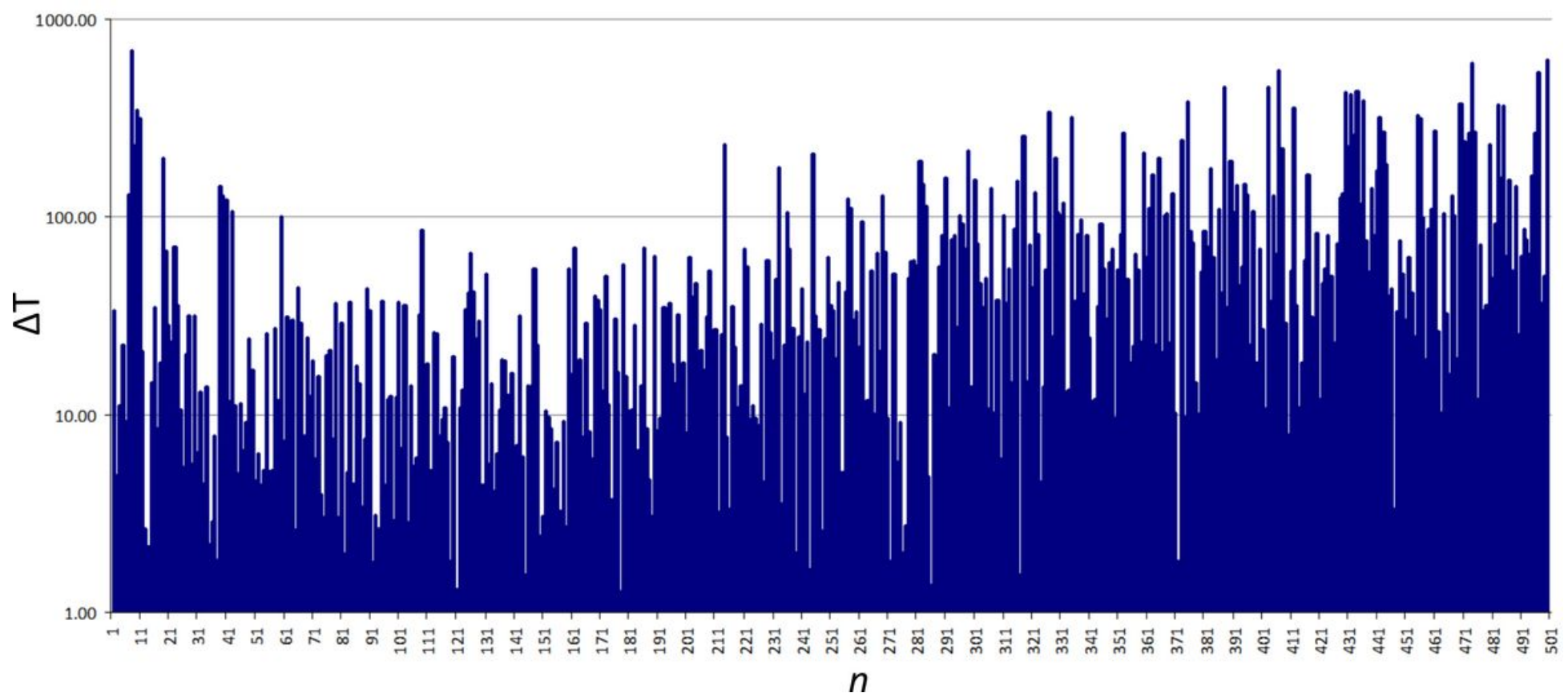


Time delays of earthquakes vs. earthquake number. The delays were shortening until the earthquake 141 (December 31st 2020), and since then the delays are prolonging.

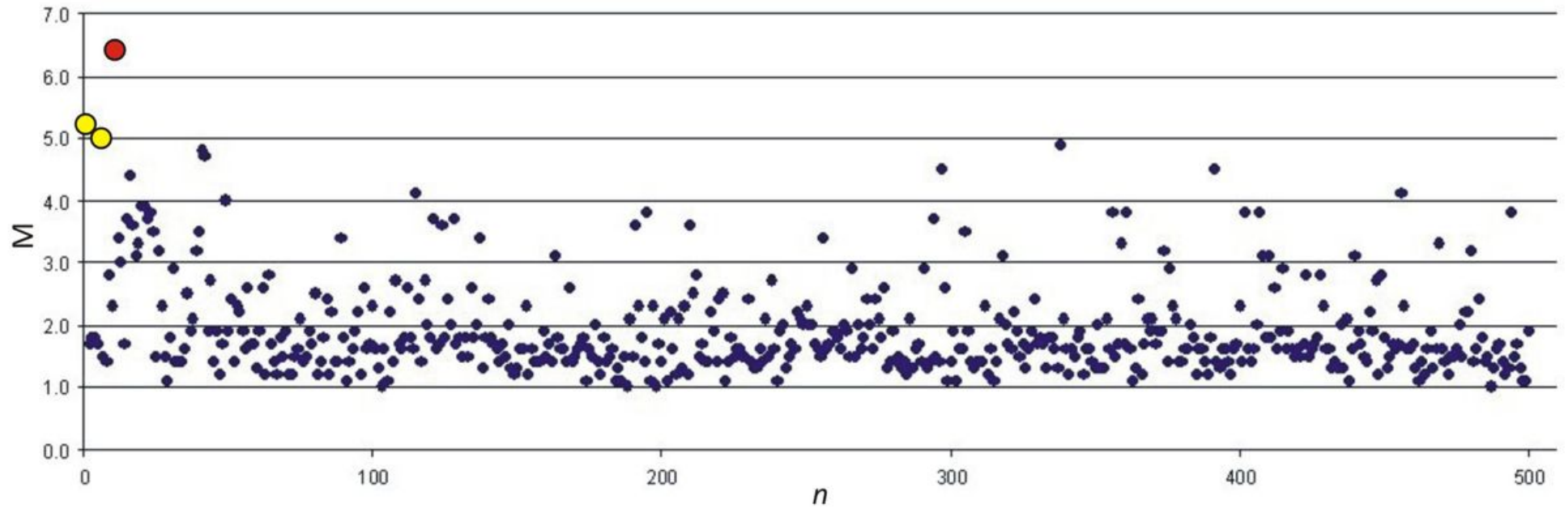

Figure 7

Magnitude vs. earthquake number shows no correlation of the two. Though the strong earthquakes (>M5.0) occurred at the beginning of 2020 seismic activity, $>$ M4.0 earthquakes occur randomly.

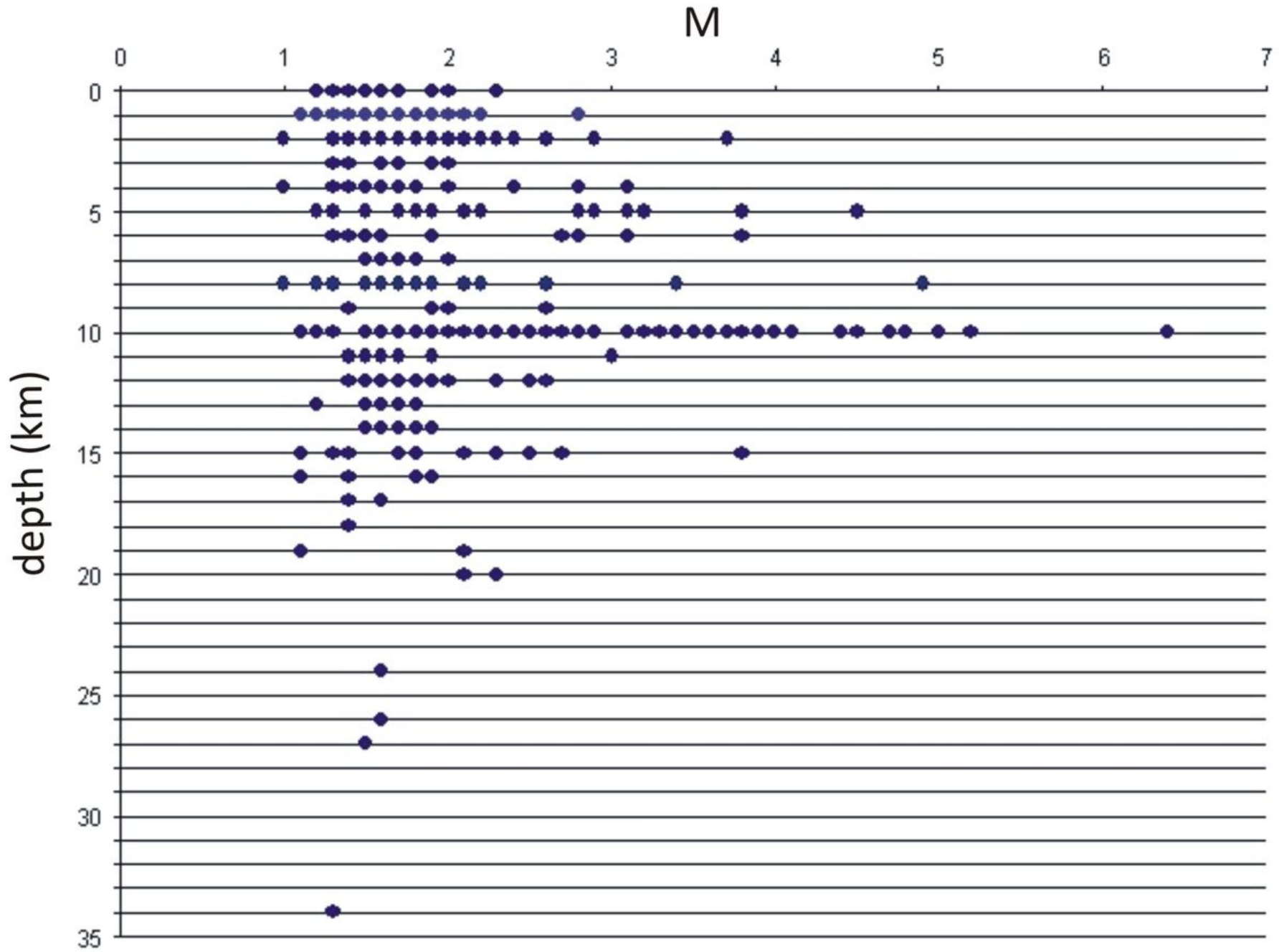

Figure 8

Hypocentre depth vs. magnitude for the first 500 earthquakes and aftershocks. The largest span of magnitudes is at the focal depth of $10 \mathrm{~km}$. Maximal magnitudes decrease with depth and the number of recorded earthquakes rapidly decreases. Very shallow foci earthquakes (0 km) have quite narrow span of magnitudes, between M.1.1 and M2.2, but were felt with intensities of $I^{\circ}$ to $\mathrm{IV}^{\circ}$ on MCS scale. 


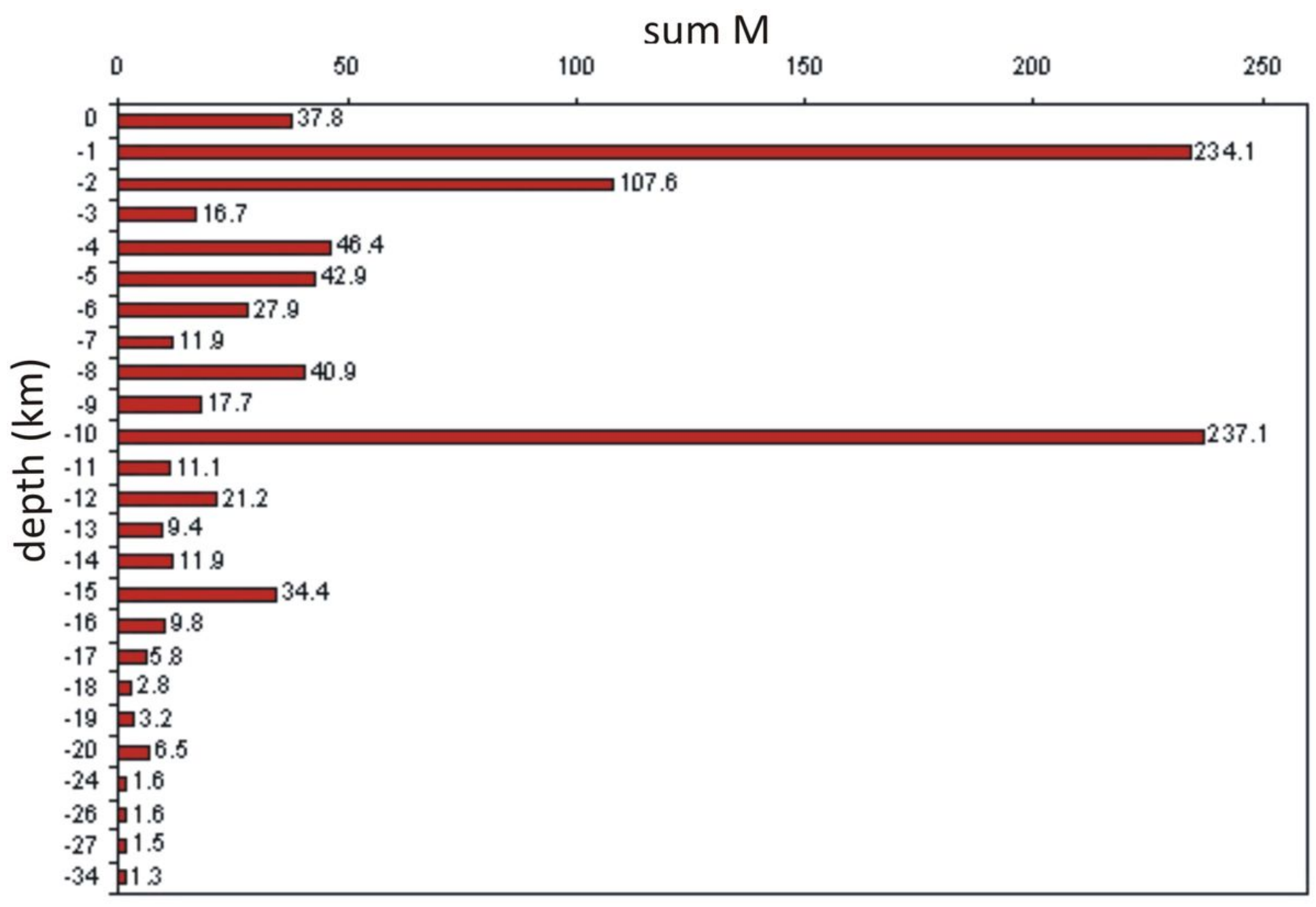

Figure 9

Hypocentre depth vs. cumulative released magnitude indicates the "efficiency" of sources at the depth. The total released magnitude of all 500 earthquakes (TM500) is 947.1. The sources at the depths of $1 \mathrm{~km}$ and $10 \mathrm{~km}$ have released greatest amount of energy, $49.8 \%$ of TM500. 


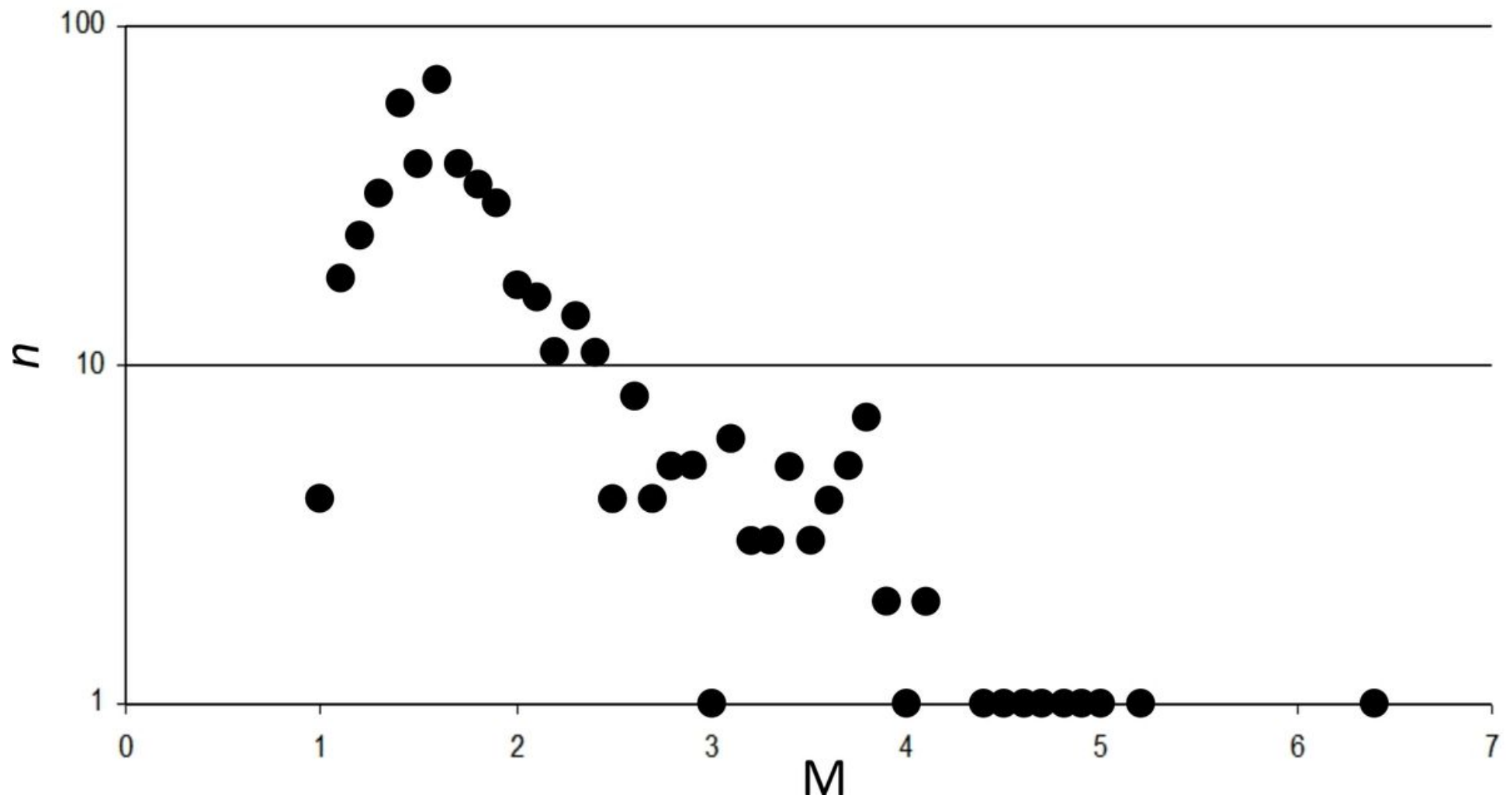

Figure 10

Frequency of earthquakes vs. their magnitude. The maximum is at M1.6 and decreases in almost linear manner until M3.5 when started short linear rise until M3.8 which is followed by rapid fall.

$\mathrm{km}$

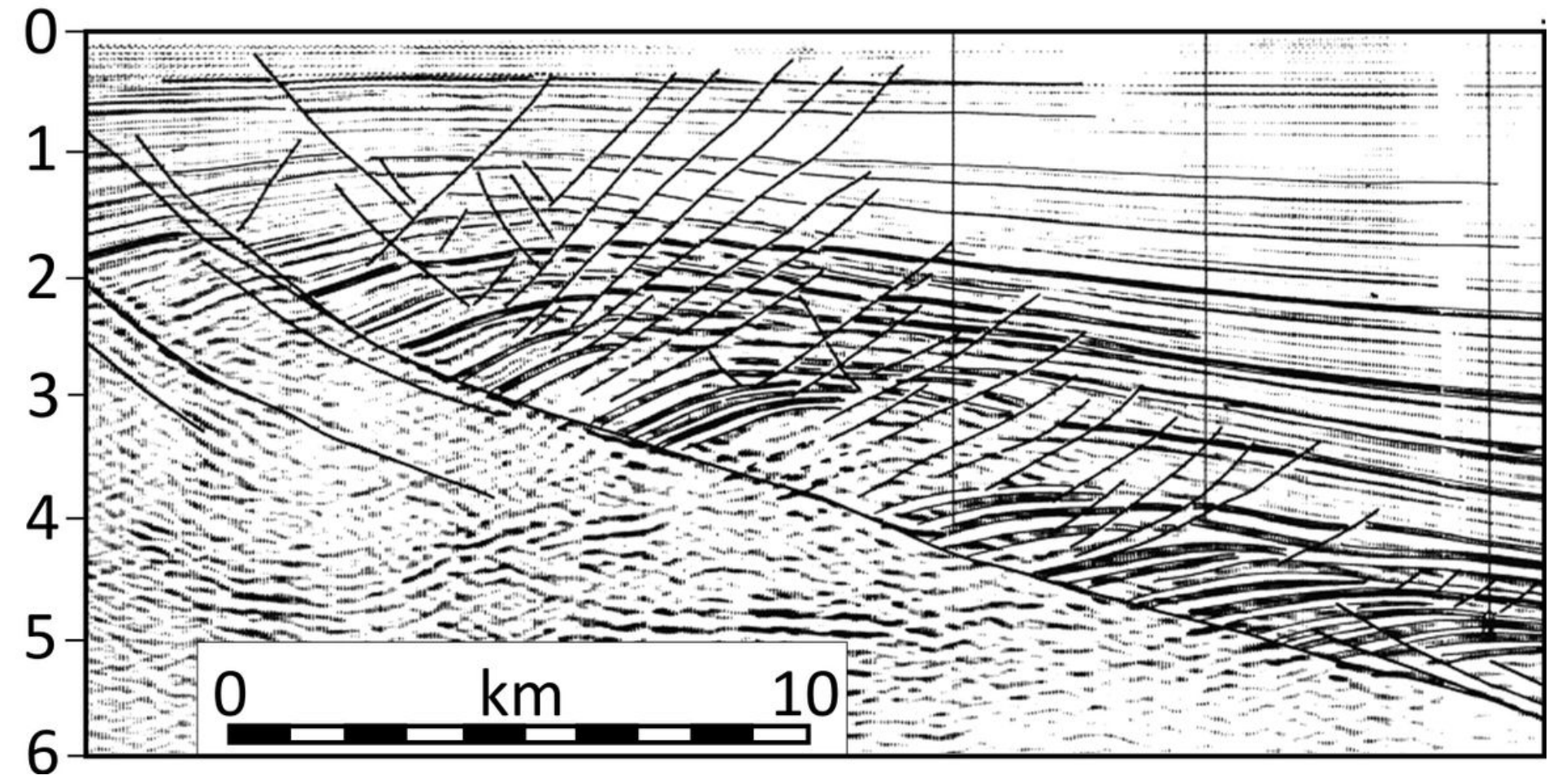

Figure 11

Listric normal fault and its faulted hanging wall. Interpreted Brazos Ridge seismic line from Christiansen (1989), shortened. 
This is a list of supplementary files associated with this preprint. Click to download.

- Petrinja2020earthquakeEMSCexport.xls 